\title{
Volume 30 Number 3
}

\section{5}

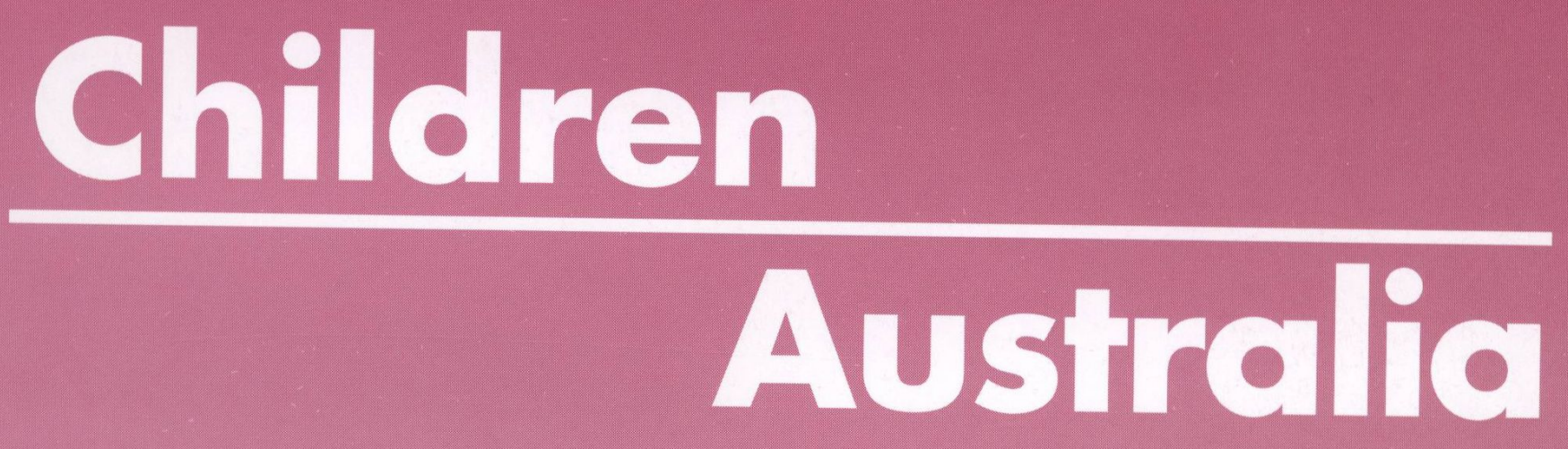

In this issue ...

Children Australia : $30^{\text {th }}$ year of publication

What have we said? What have we done?

Child protection services in Queensland post-Forde Inquiry

Foster carers in New South Wales

Profile and projections based on ABS Census data

Upping the ante!

The training and status of foster carers in Queensland

FOCUS ON PRACTICE

A checklist for organisations working with fathers

using the non-deficit approach 


\section{Children Australia}

Volume 302005

Children Australia is a quarterly journal which aims to provide an opportunity for service providers, academics and others concerned with children and tamilies to report on their work, to raise issues and to share their views.

The views expressed in Children Australia are those of the authors, and are therefore not necessarily endorsed by the Editors or members of the editorial board.

\section{CO-EDITORS: Lloyd Owen}

Dr Jennifer Lehmann

EDITORIAL ASSISTANT/SUBSCRIPTIONS:

Larraine Redshaw

c/-Oz Child: Children Australia

\section{SUBSCRIPTIONS 2005}

Standard [inc GST]

Student [inc GST]

Overseas Aus $\$ 85.00$

\section{ENQUIRIES}

For subscription enquiries, or to advise change of address, please contact:

Larraine Redshaw

Children Australia

PO Box 1312

South Melbourne

Vic 3205, Australio

Tel: [03] 96952200 Fax: [03] 96960507

Email: Iredshaw@ozchild.org.au

\section{GUIDELINES FOR CONTRIBUTORS}

Guidelines for those wishing to submit material to be considered for publication in Children Australia can be found on the inside of the back cover.

\section{NATIONAL EDITORIAL BOARD}

ACT

Dr Howard Bath

Director

The Thomas Wright Institute

NEW SOUTH WALES

Dr Elizabeth Fernandez

Senior Lecturer, School of Social Work

University of New South Wales

NORTHERN TERRITORY

Mrs Vicki O'Halloran

Chief Executive Officer

Somerville Community Services Inc.

\section{QUEENSLAND}

Ms Chris-Maree Sultmann

Encompass Family \& Community

SOUTH AUSTRALIA

Dr Freda Briggs

Emeritus Professor

University of South Australia

TASMANIA

Ms Scilla Sayer

Senior Policy Officer, Child \& Family Services

Department of Health \& Human Services

VICTORIA

Professor Chris Goddard

Interim Director

National Research Centre for the

Prevention of Child Abuse

Monash University

WESTERN AUSTRALIA

Dr David Vicary

Executive Director, Office for Children and Youth

\section{EDITORIAL CONSULTANTS}

Dr Frank Ainsworth

Research Scholar and Lecturer (Adjunct)

School of International Community \& Cultural Studies

Edith Cowan University

Associate Professor Margarita Frederico

Director, Post-graduate Programs

School of Social Work \& Social Policy

La Trobe University

\section{OZ CHILD REPRESENTATIVE}

Ms Susan Pitman

Senior Research Officer 


\section{Children Australia}

\section{CONTENTS}

Editorial 2

Jennifer Lehmann

Children Australia : $30^{\text {th }}$ year of publication

- What have we said? What have we done? 4 Jennifer Lehmann and Larraine Redshaw

Child protection services in Queensland post-Forde Inquiry

Clare Tilbury

Foster carers in New South Wales

Profile and projections based on ABS Census data

Peter Siminski, Jenny Chalmers and Marilyn McHugh

Upping the ante!

The training and status of foster carers in Queensland Anne Butcher

Book review

FOCUS ON PRACTICE

A checklist for organisations working with fathers using the non-deficit approach 32

Andrew King, Steve Sweeney and Ross Fletcher

The financial support of $\mathrm{Oz}$ Child: Children Australia is gratefully acknowledged

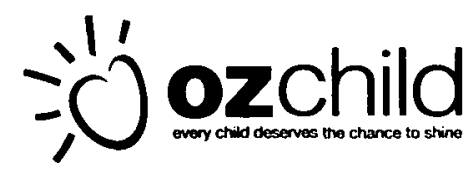

The financial support of the La Trobe University Publications Committee is gratefully acknowledged 